\title{
Penerapan Model Pemecahan Masalah Polya untuk Meningkatkan Kemampuan Menyelesaikan Masalah Soal Cerita Perbandingan dan Skala
}

\author{
Nurul Istiqomah \\ SD Negeri 5 Sidoharjo \\ nurulistiqomahh@gmail.com
}

\section{Article History \\ accepted 01/02/2020}

\begin{abstract}
The purpose of this research was to improve the ability to solve comparative story problems and scale problems throught the application of the Polya problem solving model on the fifth grade students of SD Negeri 5 Sidoharjo at 2019/2020 academic year. The form of this research was classroom action researches that consist of the cycles, each cycleconsists of planning, acting, observing, and reflecting. The subjects of this research were the fifth grade which have 15 students. Data collecting technique used are interview, observation, documentation, and test. Data analyzing technique was interactive analysis model that consist of four component: data collection, data reduction, data display, and verification. The average ability to solve problems of comparison stories and scales in the pre-cycle 55.93; cycle I 74.79; and cycle II 84.38. Classical completeness in pra-cycle was 4 students (26.67\%), cycle I was 12 students (80\%), cycle II was 15 students (100\%). The conclusion is the application of Polya's problem solving model to improve the ability to solve problems of comparasion and scale story problems in fifth grade students of SD Negeri 5 Sidoharjo at 2019/2020 academic year.
\end{abstract}

Keywords: Polya's Problem Solving Model, solving problems with stories, comparisons and scales

\section{Abstrak}

Penelitian ini bertujuan untuk meningkatkan kemampuan menyelesaikan masalah soal cerita perbandingan dan skala melalui penerapan model pemecahan masalah Polya pada siswa kelas V SD Negeri 5 Sidoharjo tahun pelajaran 2019/2020. Bentuk Penelitian ini adalah penelitian tindakan kelas yang terdiri dari dua siklus, tiap siklus terdiri dari perencanaan, pelaksanaan tindakan, observasi, dan refleksi. Subjek penelitian ini adalah siswa kelas $V$ yang berjumlah 15 siswa. Teknik pengumpulan data menggunakan wawancara, observasi, dokumentasi, dan tes. Teknik analisis data menggunakan analisis metode interaktif yang terdiri dari empat komponen, yaitu pengumpulan data, reduksi data, sajian data, dan penarikan kesimpulan. Adapun rata-rata kemampuan menyelesaikan masalah soal cerita perbandingan dan skala pada prasiklus 55,93 ; siklus I 74,79; dan siklus II 84,38. Ketuntasan klasikal pada prasiklus sebanyak 4 peserta didik (26,67\%), siklus I sebanyak 12 peserta didik (80\%), siklus II sebanyak 15 peserta didik (100\%). Simpulan penelitian ini adalah penerapan Model Pemecahan Masalah Polya untuk meningkatkan kemampuan menyelesaikan masalah soal cerita perbandingan dan skala pada siswa kelas V SD Negeri 5 Sidoharjo tahun pelajaran 2019/2020.

Kata kunci: Model Pemecahan Masalah Polya, menyelesaikan masalah soal cerita, perbandingan dan skala 


\section{PENDAHULUAN}

Sebagian besar siswa pasti menanggap matematika merupakan pelajaran yang paling sulit dibandingkan pelajaran lain. Padahal sebenarnya, matematika tidak sesulit yang dibayangkan. Matematika selalu ditemui dalam kehidupan sehari-hari. Selain itu, pelajaran matematika sangat penting terutama untuk menanamkan proses berpikir logis, analitis, sistimatis, kritis, dan kreatif.

Menurut Suherman, "Matematika kedudukannya sebagai ratunya ilmu pengetahuan dan sebagai suatu ilmu yang berfungsi untuk melayani ilmu pengetahuan. Maka matematika tumbuh dan berkembang untuk dirinya sendiri sebagai suatu ilmu, juga untuk melayani kebutuhan ilmu pengetahuan dalam pengembangan dan oprasionalnya. (2001:29). Dengan demikian, permasalahan mengenai anggapan matematika sebagai pelajaran sulit harus dipecahkan.

Ahmadi (dalam Aisyah, 2007: 6) menyatakan "Masalah yang dihadapi dalam pembelajaran matematika biasanya dinyatakan dalam bentuk soal cerita, baik tertulis ataupun lisan. Soal cerita lebih sulit dipecahkan daripada soal-soal yang melibatkan bilangan-bilangan." Sejalan dengan Ahmadi, Nafi'an pun menjelaskan bahwa berdasarkan keadaan di lapangan, masalah yang sering dirasakan sulit oleh siswa dalam pembelajaran matematika adalah menyelesaikan masalah soal cerita (2011:571). Maka diperlukan inovasi dalam pembelajaran matematika terutama penyelesaian soal cerita. Tujuannya agar permasalahan menyelesaikan masalah soal cerita matematika tidak lagi dianggap sulit oleh peserta didik.

Salah satu langkah pemecahan masalah mengenai anggapan matematika sebagai pelajaran sulit dapat menggunakan langkah pemecahan masalah dengan menerapkan Model Pemecahan Masalah Polya. Tim MKPBM menyatakan, "Langkahlangkah dalam pembelajaran pemecahan masalah menurut Polya ada 4, yaitu: (1) memahami masalah, (2) menentukan rencana strategi pemecahan masalah, (3) menyelesaikan strategi penyelesaian masalah, dan (4) memeriksa kembali jawaban yang diperoleh" (2001: 84). Hal tersebut menunjukkan bahwa metode Polya menerapkan langkah-langkah pemecahan masalah yang tersusun runtut. Langkah pemecahan yang runtut sangat dibutuhkan dalam membimbing siswa sekolah dasar untuk menyelesaikan permasalahan dalam pembelajaran matematika.

Langkah pertama dalam Model Pemecahan Masalah Polya adalah memahami masalah. Artinya, siswa harus mampu memahami permasalahan yang ada dalam soal matematika. Langkah kedua adalah menentukan rencana strategi pemecahan masalah. Pada langkah kedua ini, siswa perlu lebih dibimbing untuk menemukan rencana pemecahan masalah. Pembimbingan dapat dilakukan dengan pemberian stimulus untuk membantu proses berpikir siswa. Setelah siswa menemukan rencana pemecahan masalah, langkah ketiga adalah menyelesaikan strategi penyelesaian masalah. Artinya, siswa diminta untuk menyelesaikan masalah mengguna-kan rencana penyelesaian yang telah ditemukannya. Langkah terakhir adalah memeriksa kembali jawaban yang diperoleh. Artinya, siswa dibiasakan untuk meneliti kembali hasil penyelesaiannya sudah sesuai dengan masalah yang diberikan atau belum. Dengan demikian, Model Pemecahan Masalah Polya sangat sesuai untuk melatih siswa dalam berpikir logis, analitis, sistimatis, kritis, dan kreatif secara runtut.

Menurut hasil wawancara dengan siswa kelas V SD Negeri 5 Sidoharjo menunjukkan bahwa matematika pun menjadi pelajaran yang paling sulit dibandingkan pelajaran lain, terutama dalam menyelesaikan masalah berbentuk soal cerita. Hasil wawancara tersebut, dikuatkan dengan data yang dimiliki oleh peneliti sebagai guru kelas V. Berdasarkan data, kemampuan siswa dalam menyelesaikan masalah soal cerita menunjukkan kategori rendah.

Rendahnya kemampuan siswa dalam menyelesaikan masalah soal cerita disebabkan oleh beberapa hal. Antara lain (a) siswa masih kesulitan memahami soal cerita ditunjukkan dengan kesulitan dalam menentukan apa yang diketahui dan 
ditanyakan dalam soal cerita; (b) siswa masih kesulitan dalam menemukan rumus yang digunakan dalam penyelesaian masalah soal cerita yang diberikan; (c) siswa belum mampu menyelesaikan masalah soal cerita yang diberikan; (d) siswa hanya menjawab soal cerita sesuai dengan keinginannya sehingga jawaban sering mengalami kesalahan.

Kenyataan tersebut, dikuatkan dengan hasil pre-test yang dilaksanakan oleh peneliti yang menunjukkan bahwa sebagian besar siswa masih mendapatkan nilai di bawah KKM sebesar $\geq 60$ yang telah ditetapkan. Pada kemampuan menyelesaikan masalah soal cerita 4 siswa atau $26,67 \%$ yang mencapai KKM sebesar $\geq 60$. Sedangkan, 11 siswa atau $73,33 \%$ masih berada di bawah KKM sebesar $<60$ dengan nilai rata-rata 55,93. Berdasarkan hasil pre-test menunjukkan bahwa kemampuan menyelesaikan masalah soal cerita siswa kelas V SD Negeri 5 Sidoharjo masih rendah. Hasil pre-test ini digunakan sebagai data awal dalam penelitian ini.

Berbagai penyebab rendahnya kemampuan menyelesaikan masalah soal cerita tersebut, perlu ditemukan alternatif solusi pemecahannya. Agar rendahnya kemampuan menyelesaikan masalah soal cerita dapat diselesaikan sehingga tidak menjadi masalah yang berkelanjutan. Adapun solusi yang dapat digunakan untuk meningkatkan kemampuan menyelesaikan masalah soal cerita dapat menerapkan Model Pemecahan Masalah Polya.

Menurut Smith (dalam Amir, 2009: 27) menyatakan bahwa kelebihan model pemecahan masalah dengan Model Pemecahan Masalah Polya sebagai berikut (1) siswa terlibat langsung dengan objek nyata sehingga dapat mempermudah pemahaman siswa terhadap materi pelajaran; (2) siswa menemukan sendiri konsepkonsep yang dipelajari; (3) melatih siswa untuk berpikir lebih kritis; (4) melatih siswa untuk bertanya dan terlibat lebih aktif dalam pembelajaran; (5) mendorong siswa untuk menemukan konsep-konsep baru; (6) memberi kesempatan kepada siswa untuk belajar menggunakan metode ilmiah. Kelebihan-kelebihan tersebut merupakan sebuah proses dalam pembelajaran yang bermakna dan berpikir tingkat tinggi bagi peserta didik.

Sedangkan menurut Smith (dalam Amir, 2009: 27), kelemahan model pemecahan masalah dengan Model Pemecahan Masalah Polya sebagai berikut (1) memerlukan waktu yang cukup banyak; (2) tidak dapat dipergunakan di kelas rendah; (3) menjadikan pembelajaran yang tertinggal sebab satu dua masalah yang sulit dipecahkan memakan waktu yang tidak sedikit. Kelemahan-kelemahan tersebut dapat diatasi dengan membiasakan peserta didik menggunakan model pemecahan masalah dengan Model Pemecahan Masalah Polya tersebut. Apabila peserta didik telah terbiasa dalam menyelesaikan masalah soal cerita dengan model pemecahan masalah dengan Model Pemecahan Masalah Polya, maka peserta didik akan semakin terampil dalam mengerjakan soal ceriita.

Pelaksanaan penerapan model Polya untuk meningkatkan kemampuan menyelesaikan masalah soal cerita dalam materi perbandingan dan skala. Pemilihan materi perbandingan dan skala didasarkan pada pertimbangan perbandingan dan skala sebagai salah satu materi yang sulit di kelas $\mathrm{V}$ yang dialami oleh siswa dari waktu ke waktu.

Adapun tujuan yang ingin dicapai dalam penelitian ini adalah untuk meningkatkan kemampuan menyelesaikan masalah soal cerita perbandingan dan skala dengan menerapkan Model Pemecahan Masalah Polya pada siswa kelas V SD Negeri 5 Sidoharjo tahun pelajaran 2019/2020. 


\section{METODE}

Penelitian ini dilaksanakan di SD Negeri 5 Sidoharjo. Subjek penelitian ini adalah siswa kelas $\mathrm{V}$ berjumlah 15 siswa, terdiri dari 7 siswa laki-laki dan 8 siswa perempuan. Waktu penelitian dilaksanakan selama 2 bulan yaitu Oktober - Desember 2019 tahun pelajaran 2019/2020.

Bentuk penelitian ini adalah penelitian tindakan kelas (PTK) yang berlangsung selama dua siklus. Setiap siklus terdiri dari empat tahap sebagai berikut: 1) perencanaan (planning); 2) pelaksanaan tindakan (acting); 3) observasi (observing); dan 4) refleksi (reflecting).

Data penelitian ini adalah data kuantitatif dan kualitatif. Adapun yang termasuk data kuantitatif dalam penelitian ini adalah hasl pre-test kemampuan menyelesaikan masalah soal cerita perbandingan dan skala dan hasil tes kemampuan menyelesaikan masalah soal cerita perbandingan dan skala. Data kualitatif adalah hasil wawancara dengan siswa kelas V SD Negeri 5 Sidoharjo, silabus pembelajaran, dan Rencana Pelaksanaan Pembelajaran (RPP).

Teknik pengumpulan data yaitu wawancara, observasi, dokumentasi, dan tes. Validitas data adalah validitas isi, triangulasi sumber, dan teknik pengumpulan data. Data yang diperoleh dalam penelitian ini dianalisis menggunakan model analisis interaktif yang terdiri dari kegiatan pengumpulan data (data collection), reduksi data (data reduction), penyajian data (data display), dan penarikan kesimpulan (verification).

\section{HASIL DAN PEMBAHASAN}

Berdasarkan hasil wawancara, observasi, dan pretest yang dilakukan peneliti pada kelas V SD Negeri 5 Sidoharjo tahun pelajaran 2019/2020 menunjukkan bahwa kemampuan menyelesaikan masalah soal cerita perbandingan dan skala masih rendah. Hasil pretest yang dilakukan sebagian besar peserta didik belum mencapai KKM sebesar $\geq 60$, yaitu sebanyak 11 peserta didik. Hanya 4 peserta didik yang dapat mencapai KKM sebesar $\geq 60$. Hasil selengkapnya dapat dilihat pada Tabel 1 sebagai berikut

\section{Tabel 1. Frekuensi Data Nilai Kemampuan Menyelesaikan masalah soal cerita} Perbandingan dan skala Pra-siklus

\begin{tabular}{lcccc}
\hline \multicolumn{1}{c}{ Interval } & $\mathbf{X i}$ & $\mathbf{F i}$ & $\mathbf{X i . F i}$ & Persentase \\
\hline $47-51$ & 49,5 & 4 & 198 & $26,67 \%$ \\
\hline $52-56$ & 54,5 & 2 & 109 & $13,33 \%$ \\
\hline $57-61$ & 59,5 & 5 & 297,5 & $33,33 \%$ \\
\hline $62-66$ & 64,5 & 2 & 129 & $13,33 \%$ \\
\hline $67-71$ & 69,5 & 2 & 139 & $13,33 \%$ \\
\hline Jumlah & & 15 & 872,5 & $100 \%$ \\
\hline Nilai Tertinggi & & & 67 \\
\hline Nilai Terendah & & & 47 \\
\hline \multicolumn{2}{l}{ Rata-rata Kelas } \\
\hline
\end{tabular}

Berdasarkan data pada Tabel 1, menunjukkan bahwa sebanyak 15 peserta didik atau $73,33 \%$ belum mencapai $\mathrm{KKM}$ sebesar $\geq 60$, sedangkan 4 siswa sebanyak $26,67 \%$ telah mencapai KKM sebesar $\geq 60$. Nilai terendah adalah 47 dan nilai tertinggi adalah 67. Nilai rata-rata kelas sebesar 55,93. Adapun skor hasil pengamatan aktivitas peserta didik prasiklus diperoleh rata-rata kelas sebesar 4 kategori kurang baik (KB).

Pelaksanaan pembelajaran menyelesaikan masalah soal cerita perbandingan dan skala siklus I, dilakukan tindakan yaitu dengan menerapkan Model Pemecahan 
Masalah Polya. Setelah dilakukan tindakan siklus I terjadi peningkatan kemampuan menyelesaikan masalah soal cerita perbandingan dan skala. Hasil selengkapnya dapat dilihat pada Tabel 2 sebagai berikut:

\section{Tabel 2. Frekuensi Data Nilai Kemampuan Menyelesaikan masalah soal cerita} Perbandingan dan skala Siklus I

\begin{tabular}{lcccc}
\hline \multicolumn{1}{c}{ Interval } & $\mathbf{X i}$ & $\mathbf{F i}$ & $\mathbf{X i . F i}$ & Persentase \\
\hline $50-59$ & 54,5 & 3 & 163,5 & $20 \%$ \\
\hline $60-69$ & 64,5 & 2 & 129 & $13,33 \%$ \\
\hline $70-79$ & 74,5 & 3 & 223,5 & $20 \%$ \\
\hline $80-89$ & 84,5 & 7 & 591,5 & $46,67 \%$ \\
\hline Jumlah & & 15 & 1107,5 & $100 \%$ \\
\hline Nilai Tertinggi & & & & 88,13 \\
\hline Nilai Terendah & & & & 75,63 \\
\hline Rata-rata Kelas & & & $80 \%$ \\
\hline Ketuntasan Klasikal & & &
\end{tabular}

Berdasarkan data pada Tabel 2, menunjukkan bahwa peserta didik yang telah berhasil mencapai $\mathrm{KKM} \geq 60$ sebanyak 12 peserta didik atau $80 \%$, sedangkan 3 peserta didik atau $20 \%$ belum mencapai KKM sebesar $\geq 60$. Adapun nilai terendah adalah 55,63 dan nilai tertinggi adalah 88,13 . Sedangkan rata-rata kelas 74,79 . Akan tetapi, indikator kinerja sebanyak $100 \%$ peserta didik memperoleh nilai sebesar $\geq 60$ belum tercapai.

Selain data nilai kemampuan menyelesaikan masalah soal cerita perbandingan dan skala, aktivitas peserta didik selama pembelajaran pun diamati. Berdasarkan hasil pengamatan aktivitas peserta didik selama pada siklus I diperoleh rata-rata kelas sebesar 17 termasuk kategori (B). Artinya aktivitas peserta didik selama pembelajaran siklus I sudah menunjukkan keaktifan dalam pembelajaran.

Selanjutnya, untuk perbaikan dan peningkatan pelaksanaan pembelajaran menyelesaikan masalah soal cerita perbandingan dan skala dengan menerapkan Model Pemecahan Masalah Polya siklus I dilaksanakan pada siklus II. Setelah dilaksanakan pembelajaran siklus II dengan menerapkan Model Pemecahan Masalah Polya menunjukkan peningkatan nilai kemampuan menyelesaikan masalah soal cerita perbandingan dan skala. Hasil selengkapnya dapat dilihat pada Tabel 3 sebagai berikut

Tabel 3. Frekuensi Data Nilai Kemampuan Menyelesaikan masalah soal cerita Perbandingan dan skala Siklus II

\begin{tabular}{lllll}
\hline Interval & $\mathbf{X i}$ & $\mathbf{F i}$ & $\mathbf{X i . F i}$ & Persentase \\
\hline $61-70$ & 65,5 & 3 & 196,5 & $20 \%$ \\
\hline $71-80$ & 75,5 & 1 & 75,5 & $6,67 \%$ \\
\hline $81-90$ & 85,5 & 4 & 342 & $26,67 \%$ \\
\hline $91-100$ & 95,5 & 7 & 668,5 & $46,67 \%$ \\
\hline Jumlah & & 15 & 1282,5 & $100 \%$ \\
\hline Nilai Tertinggi & & & & 100 \\
\hline Nilai Terendah & & & 61,88 \\
\hline Rata-rata Kelas & & & 84,38 \\
\hline Ketuntasan Klasikal & & & $100 \%$ \\
\hline
\end{tabular}


Berdasarkan data pada Tabel 3, menunjukkan bahwa peserta didik yang telah berhasil mencapai KKM sebesar $\geq 60$ sebanyak 15 peserta didik atau $100 \%$. Artinya keseluruhan peserta didik telah mampu mencapai KKM yang telah ditetapkan sebesar $\geq 60$. Hal tersebut menandakan pula, indikator kinerja dapat tercapai.

Adapun nilai terendah adalah 61,88 dan nilai tertinggi adalah 100. Rata-rata kelas mencapai 84,38 . Hasil yang diperoleh menunjukkan peningkatan dibandingkan pada siklus I.

Skor hasil pengamatan aktivitas peserta didik siklus II diperoleh skor rata-rata kelas sebenar 23 termasuk kategori sangat baik (SB). Data tersebut menunjukkan bahwa aktivitas peserta didik selama pembelajaran menyelesaikan masalah soal cerita perbandingan dan skala dengan menerapkan Model Pemecahan Masalah Polya mengalami peningkatan yang signifikan.

Berdasarkan data-data yang telah diperoleh menunjukkan bahwa kemampuan menyelesaikan masalah soal cerita perbandingan dan skala serta aktivitas peserta didik kelas V SD Negeri 5 Sidoharjo pada siklus II mengalami peningkatan. Selain itu, indikator kinerja sebesar $100 \%$ peserta didik memperoleh sesuai KKM yang telah ditentukan yaitu $\geq 60$. Artinya keseluruhan peserta didik kelas $V$ yaitu 15 anak telah mencapai $\mathrm{KKM}$ sebesar $\geq 60$. Serta pengamatan aktivitas belajar peserta didik pun termasuk dalam kategori sangat baik (SB). Oleh karena itu, penelitian ini dihentikan pada siklus II.

Data-data yang telah diperoleh dari prasiklus, siklus I, dan siklus II dikajikan sesuai dengan rumusan masalah dan selanjutnya dikaitkan dengan teori yang telah dikemukakan. Berdasarkan hasil observasi, tes, dan analisis data, penelitian ini menunjukkan adanya peningkatan nilai keterampilan menyelesaikan masalah soal cerita perbandingan dan skala serta aktivitas peserta didik dalam pembelajaran menyelesaikan masalah soal cerita perbandingan dan skala dengan menerapkan Model Pemecahan Masalah Polya pada peserta didik kelas V SD Negeri 5 Sidoharjo tahun pelajaran 2019/2020 pada setiap siklus.

Peningkatan nilai keterampilan menyelesaikan masalah soal cerita perbandingan dan skala serta ativitas peserta didik pada penelitian ini terjadis ecara bertahap. Peningkatan tersebut dapat dilihat pada Tabel 5 sebagai berikut

Tabel 5. Data Peningkatan Kemampuan Menyelesaikan masalah soal cerita Perbandingan dan Skala serta Aktivitas Peserta Didik Prasiklus, Siklus I, dan Siklus II

\begin{tabular}{lccc}
\hline Aspek & Prasiklus & Siklus I & Siklus II \\
\hline Rata-rata Kelas & 55,93 & 74,79 & 84,38 \\
\hline Tuntas & 4 & 12 & 15 \\
\hline Tidak Tuntas & 11 & 3 & - \\
\hline Ketuntasan Klasikal & $26,67 \%$ & $80 \%$ & $100 \%$ \\
\hline Aktivitas Peserta Didik & 4 & 17 & 23 \\
Skor Rata-Rata Kelas & Kurang Baik & Baik & Sangat Baik \\
\hline
\end{tabular}

Berdasarkan Tabel 5 menunjukkan bahwa dengan menerapkan Model Pemecahan Masalah Polya dapat meningkatkan kemampuan menyelesaikan masalah soal cerita perbandingan dan skala. Hasil ini sesuai dengan penelitian yang dilakukan oleh Dewi (2014) yang berjudul "Penerapan Model Polya untuk Meningkatkan Hasil Belajar dalam Memecahkan Soal Cerita Matematika Siswa Kelas V SDN No. 2 Sepang Tahun Pelajaran 2012/2013". Hasil Penelitian menunjukkan adanya peningkatan ketuntasan hasil belajar matematika pada siklus I sebesar $71,07 \%$ dan siklus II 
90,35 \%. Dengan demikian, penelitian tersebut menunjukkan bahwa terjadi peningkatan hasil belajar sebesar 19,28 \% dari siklus I ke siklus II.

Meningkatnya kemampuan menyelesaikan masalah soal cerita perbandingan dan skala pada peserta didik dikarenakan pelaksanaan pembelajaran yang menerapkan Model Pemecahan Masalah Polya, peserta didik berpartisipasi aktif selama pembelajaran. Selain itu, penerapan Model Pemecahan Masalah Polya pun memfasilitasi peserta didik untuk meningkatkan kemampuan 4C (citical thinking, creative, collaborative, communicative).

Adapun langkah-langkah pada model pemecahan masalah Polya (1) memahami masalah, artinya peserta didik memahami permasalahan yang disajikan dalam soal cerita perbandingan dan skala dengan menuliskan yang diketahui dan ditanyakan yaitu kemampuan critical thinking; (2) menentukan rencana strategi pemecahan masalah, artinya peserta didik menentukan rumus yang digunakan untuk menyelesaikan masalah soal cerita perbandingan dan skala, yaitu kemampuan critical thinking, collaborative, dan creative; (3) menyelesaikan strategi penyelesaian masalah, artinya peserta didik menyelesaikan masalah soal cerita perbandingan dan skala menggunakan rumus yang telah direncanakan, yaitu kemampuan critical thinking; (4) memeriksa kembali jawaban yang diperoleh, artinya setelah peserta didik menemukan jawabannya peserta didik masih mempunyai tugas untuk memeriksa jawabannya sudah benar atau belum kemudian menyampaikan proses dan hasilnya, yaitu kemampuan communicative.

\section{SIMPULAN}

Berdasarkan hasil analisis data yang diperoleh pada siklus I dan siklus II yang telah dilaksanakan, maka dapat disimpulkan bahwa penerapan model pemecahan masalah Polya dapat meningkatkan kemampuan menyelesaikan masalah soal cerita perbandingan dan skala pada peserta didik kelas V SD Negeri 5 Sidoharjo tahun pelajaran 2019/2020. Selain itu, juga dapat meningkatkan aktivitas peserta didik dalam pembelajaran menyelesaikan masalah soal cerita perbandingan dan skala.

Peningkatan kemampuan menyelesaikan masalah soal cerita perbandingan dan skala dapat dibuktikan dengan rata-rata kelas dan ketuntasan klasikal peserta didik pada setiap siklusnya. Rata-rata kemampuan menyelesaikan masalah soal cerita perbandingan dan skala pada prasiklus 55,93; siklus I 74,79; dan siklus II 84,38. Ketuntasan klasikal pada prasiklus sebanyak 4 peserta didik $(26,67 \%)$, siklus I sebanyak 12 peserta didik (80\%), siklus II sebanyak 15 peserta ddik (100\%). Sedangkan skor rata-rata aktivitas peserta didik pada prasiklus sebesar 4 termasuk kategori kurang baik; siklus I sebesar 17 termasuk kategori baik, dan siklus II sebesar 23 termasuk kategori sangat baik. Dengan demikian, secara klasikal kemampuan menyelesaikan masalah soal cerita perbandingan dan skala telah mencapai indikator kinerja sebesar $100 \%$ peserta didik mencapai KKM $(\geq 60)$.

\section{DAFTAR PUSTAKA}

Aisyah, Nimas. (2007). Pengembangan Pembelajaran Matematika SD. Jakarta: Direktorat Jenderal Pendidikan Tinggi Departemen Pendidikan Nasional.

Amir, M. Taufiq. (2009). Inovasi Pendidikan Melalui Problem Based Learning. Jakarta : Kencana Prenada Media Group.

Dewi, Sari Kusuma. (2014). Penerapan Model Polya Untuk Meningkaykan Hasil Belajar Dalam Memecahkan Soal Cerita Matematika Siswa Kelas V SDN No.2 Sepang Tahun Pelajaran 2012/2013. Skripsi. Universitas Pendidikan Ganesha. 
Volume 8 Nomor 1 Tahun 2020

Nafi'an, M.I. (2011). Kemampuan Siswa dalam Menyelesaikan masalah soal cerita Ditinjau Dari Gender di Sekolah Dasar. Prosiding Makalah Seminar Nasional Matematika dan Pendidikan Matematika, hlm. MP-571 - MP-577. Yogyakarta. FMIPA Universitas Negeri Yogyakarta.

Suherman, Erman. (2001). Strategi Pembelajaran Matematika Kontemporer. Bandung: JICA.

TIM MKPBM Jurusan Pendidikan Matematika. (2001). Strategi Pembelajaran Kontemporer. Bandung: FPMIPA UPI 